\title{
ПРОФЕСІЙНА УСПІШНІСТЬ МАЙБУТНІХ ПСИХОЛОГІВ У СУСПІЛЬСТВІ РИЗИКУ
}

УДК: 159.9

\section{Чугуева Інна Євгенівна}

Кандидат психологічних наук, доиент кафедри психологї, Миколаӥвський національний університет імені В. О. Сухомлинського, м. Миколаӥв (Украйна)

\section{Кузнецова Світлана Валерї̈на}

Викладач кафедри психології, Миколаӥвський начіональний університет імені В. О. Сухомлинського, м. Миколаїв (Україна)

\begin{abstract}
Анотація. Розглянуто проблему професійної успішності майбутніх психологів у суспільстві ризику. Охарактеризовано основні психологічні компоненти професійної успішності. Розглянуто зв'язок професійної успішності у суспільстві ризику з умінням розв 'язувати складні життеві ситуації. Обтрунтовано доцільність залучення майбутніх психологів у вирішенні складних життєвих ситуацій як иуіннісно-смислової основи до особистісної освітньої парадигми. Запропоновано осмислення нових цілей $i$ засобів, світоглядних орієнтирів $i$ форм організації освітньої діяльності з урахуванням вимог формування ци розвитку уміння впоратись як 3 проблемними ситуаціями взагалі, так $i$ з ситуаціями ризику зокрема. Визначено, щэо в умовах суспільства ризику професійна задача практикуючого психолога набуває нового значення формування у людини особливої культури сочіальної та індивідуальної життєдіяльності $з$ дотриманням вимог антропологічної, соціальної, психологічної безпеки.
\end{abstract}

Ключові слова: професійна успішність, суспільство ризику, складна життєва ситуація, особистісна освітня парадигма, індивідуальна життєдіяльність.

Постановка проблеми. Сучасне суспільство характеризується стрімкістю і системністю соціальних та політичних змін, що кардинально підвищує нестабільність, невизначеність, непередбачуваність розвитку як окремої людини, так і суспільства в цілому. Відбувається тотальне проникнення ризиків в усі сфери життєдіяльності людей. Масштаби і характер людської діяльності набули такої якості, що виробництво ризиків почало перевищувати виробництво благ [1].

Небезпеки і загрози у сфері суспільного життя поставили стратегічну проблему антропологічної безпеки, яка поєднує в собі зокрема екологічний, соціальний і психологічний компоненти. При цьому значно підвищується індивідуалізація відповідальності за управління і мінімізацію ризиків. Отже, здійснення 
життєтворчості у соціально продуктивних i конструктивних формах виступає важливим чинником соціальної та індивідуальної безпеки. Але знаходження та освоєння таких форм в умовах ускладнення соціальних практик, плюралізації життєвих стратегій і стилів, поглиблення невідповідності між новою системою вимог і можливостями особистості стає для людини надзвичайно важким життєвим завданням. В індивідуальному житті людини загострюється проблема екзистенціальної безпеки. Це зумовлено тим, що у суспільстві ризику людина перебуває у ситуації довготривалого стресу, пов'язаного з тривогою за своє благополуччя (фізіологічне, психологічне, духовне, соціальне, економічне), здоров'я, автентичність, темпоральну єдність, особисте життя в цілому. В цьому сенсі професійна сфера життя виступає сферою ризиків, оскільки від неї великою мірою залежать певні складові благополуччя як окремої особистості, так i суспільства в цілому. I загалом життєдіяльність людини набуває все більш ризикованого характеру.

За таких умов особливої актуальності набуває провідна задача психології, а саме практикуючого психолога, яка формулюється словами А. Маслоу - «допомогти людині стати тим, ким вона здатна стати» [6]. В умовах суспільства ризику ця задача, окрім основного, набуває і нового значення - формування у людини особливої культури соціальної та індивідуальної життєдіяльності 3 дотриманням вимог антропологічної, соціальної, психологічної безпеки. Що ж стосується професійної сфери, то саме професійна успішність найбільшою мірою виступає чинником регуляції і мінімізації ризиків, тому що більшість соціальних ризиків в багатьох випадках пов'язані 3 проблемами ефективного виконання професійній діяльності, професійних досягнень i статусу, професійної затребуваності, самореалізації людини в професії.

Професія психолога у цьому зв'язку виступає особливою сферою, оскільки 3 кожним роком на неї зростає попит на ринку праці і усі сфери соціальної практики (система освіти, медицина, правоохоронна діяльність, військова сфера, соціальна робота, сфера бізнесу та ін.) потребують якісної психологічної допомоги і супроводу. Сьогодні навіть важко представити будь-яку галузь або сферу діяльності, яка б не затребувала у якості іï активного учасника практичного психолога з його знаннями $\mathrm{i}$ технологіями. Це у котрий раз підкреслює, що сучасна психологічна наука стає все більше і більше практико-орієнтованою, а психологи - необхідними фахівцями, які покликані допомогти суспільству, кожному громадянину знайти відповіді на нагальні питання сьогодення, здійснювати психологічну підтримку тим, хто опинився у складних життєвих ситуаціях.

На цей запит сучасного суспільства може дати відповідь освіта, зокрема іiї соціальнопсихологічна складова, але для цього необхідним є осмислення нових цілей і засобів, світо- 
глядних орієнтирів і форм організації освітньої діяльності з урахуванням вимог формування й розвитку уміння впоратись як $з$ проблемними ситуаціями взагалі, так і з ситуаціями ризику зокрема.

Стан розробки проблеми. Ще в $70-\mathrm{x}$ роках XX століття доповідь «Вчитися, щоб бути», яка була підготовлена для ЮНЕСКО (П. Друкер, П. Фрейре, Е. Фор), а також доповідь Римського клубу «Немає межі навчанню» (Д. Боткін, М. Ельмандиро, М. Малійц) відбили в собі ідеї, які покладені в основу діючої концепції освіти XXI століття. В цій концепції визначені чотири ключові елементи: навчитися пізнавати, навчитися робити, навчитися жити разом, навчитися жити.

Оскільки сучасна місія освіти - підготувати людину до входження в соціум, зробити iii здатною розв'язувати нагальні проблеми, то значна частина відповідальності за цю справу покладається на психолога, оскільки інструментом його роботи є особистість. Саме через це майбутньому психологу треба забезпечити належну фахову підготовку, яка зумовлює високий рівень його соціальної зрілості, освіченості та культури.

Розглядаючи проблему професійної успішності майбутніх психологів, зазначимо, що професійний та особистісний аспекти, які $\epsilon$ взаємопов'язаними взаємообумовленими, складають суть проблематики професійного становлення особистості. Ця проблематика посідає чільне місце в наукових працях бага- тьох українських вчених (О. Ф. Бондаренко, С. Д. Максименко, В. Г. Панок, Н. І. Пав'якель, Н. В. Чепелева, Т. С. Яценко, Ю. Г. Долінська, М. М. Заброцький, Л. Г. Терлецька, Т. М. Титаренко та ін.).

Мета статті. Уточнити концептуальні соціально-психологічні контури професійної успішності майбутніх психологів з урахуванням специфіки суспільства ризику.

Виклад основного матеріалу. В другій половині XX століття в психології з'явилися одразу декілька ідей, які мають безпосереднє відношення до професійної успішності як складової загального особистісного розвитку, зростання, зрілості: «людина для себе», (Е. Фромм), «самоактуалізація» (А. Маслоу), «Я-концепція» (К. Роджерс), «стиль життя», «наука жити» (А. Адлер), «самість» (К. Юнг), «акмеологія» (О. Деркач).

Професійна успішність відбилася в концепціях: «стиль діяльності», «психологія професіонала» (Є. О. Клімов, А. К. Маркова), «професійне самовизначення» (Г. С. Костюк, H. С. Пряжніков), «професійна ідентичність» (Н. Л. Іванова), «професійне становлення» (С. Д. Максименко, Є. Зеєр), «постіндустріальна освіта», «розвиток компетентного, конкурентоспроможного професіонала» (О. М. Новіков).

Професійна успішність як поняття має багато складових свого змісту, вона містить в собі індивідуальний, соціальний, економічний, функціонально-діяльнісний компоненти, 
які розкривають зміст цього поняття і у загальному обсязі, і в кожному конкретному прикладі. Професійна успішність - це певний результат, який створюється в процесі засвоєння, опанування і здійснення людиною своєї професійної діяльності. Першим етапом досягнення професійної успішності виступає професійне навчання. Таким чином, навчання виступає відправною точкою і визначальним вектором на шляху досягнення професійної успішності.

Як складне явище, професійна успішність майбутніх психологів розглядається в багатьох аспектах, які взаємопов'язані між собою і взаємодоповнюють один одного.

Мотиваційний аспект професійної діяльності психолога відображає спрямованість його на досягнення професійного успіху, зумовлює здатність долати певні труднощі на цьому шляху, віддзеркалює стратегічні цілі, тактичні засоби і особисті наміри психолога в професійній сфері.

Функціональний аспект пов'язаний 3 критеріями успішності, які є специфічними для професії психолога, з тим рівнем професійних знань умінь, навичок, компетенцій i компетентності, які дозволяють йому успішно виконувати свою професійну діяльність. Слід зазначити, що функціональний аспект професійної успішності $є$ динамічним утворенням і постійно змінюється у відповідності до реальних умов діяльності, іiї перспективних завдань, соціальної місії професії на певному історичному етапі, суспільних вимог і стратегічних напрямів розвитку суспільства.

Соціальний компонент відображає ступінь визнання соціумом тих чи інших професійних досягнень, рівні цього визнання, престиж професії психолога в суспільстві, ставлення суспільства до особистості психолога, визнання значущості успіхів особистості в професії з боку формальних і неформальних груп.

Економічний аспект пов'язаний зі ступенем матеріальної винагороди за успішну працю, певні досягнення в професійній діяльності, відображує загальнодержавну політику по відношенню до певного виду праці, а також ступінь неформального визнання успішності конкретних професіоналів в суспільстві, яке відбивається у певних видах приватної винагороди.

Особистісний аспект професійної успішності відображає особисте ставлення психолога до власної професійної успішності, тобто відбиває його компоненти в Я-концепції, показує рівень свідомого ставлення до обраної професії, уявлення себе в цій професії, свого особистого професійного шляху, перспектив і досягнень.

Аксіологічний аспект, пов'язаний 3 особистісним і соціальним аспектами, розкриває ступінь цінності професійного успіху в житті людини, як пов'язується професійний успіх і сенс її життя, яку ціну готова заплатити людина за успіх в професії.

Деонтологічний аспект розкриває зв'язок професійної успішності і професійної етики, як співіснують і взаємодіють між собою 
морально-етичні засади певної професійної діяльності й прагнення психолога досягти успіху в професії за будь-яку ціну, іноді всупереч професійній етиці, чи навпаки - досягнення успіху в професії неможливо без суворого дотримання професійно-етичних норм.

Таким чином, професійна успішність як багатоаспектне, складне явище потребує осмислення і рефлексії на рівні ефективного професійного розвитку й перспективи, самопроектування, особистісного вдосконалення i зростання, самореалізації і самоздійснення.

Професійна діяльність майбутніх психологів різнобічна: необхідно вирішувати конфліктні ситуації, вміти розуміти людину, правильно будувати взаємовідносини з керівництвом, дітьми, батьками, підпорядковуватися іншим, навчати та навчатись, створювати при цьому благополучний психологічний клімат у колективі.

Одним із стрижневих компонентів у професійній діяльності сучасних психологів $€$ уміння професійно діяти в умовах суспільства ризику. Суспільство ризику характеризується тим, що особистість постійно занурюється в неперервний потік складних життєвих ситуацій, від типових, суто індивідуальних, до суспільних і глобальних. До типових індивідуальних життєвих ситуацій відносять смерть близької людини, насилля, хворобу, травму, втрату роботи, сімейні ситуації, початок і закінчення навчання та ін. До суспільних і глобальних відносять військові дії, вимушене пересе- лення, соціально-економічні кризи, екологічні небезпеки, міжнаціональні конфлікти, терористичні акти, техногенні катастрофи, екстремальні умови, стихійні лиха тощо. Слід відмітити, що зазначені складні життєві ситуації не є вичерпаними.

Людина реагує на ті чи інші життєві ситуації по-різному, залежно від іiі індивідуальних особливостей. Особистість, знаходячись у складних ситуаціях, часто не в змозі самостійно вирішити проблеми життєдіяльності, що виникли у неї під впливом тих чи інших обставин. Необхідно зазначити, що кожна людина в різні періоди свого життя, в залежності від соціальних умов, у яких вона може опинитися з невідомих для неї причин, буде в певній мірі потребувати допомоги, підтримки кваліфікованого психолога.

Зрозуміло, що ці психотравмуючі події зачіпають базові цінності людини відносно власного «Я», оточуючого світу, майбутнього, а воно набагато більше детермінує розвиток особистості, ніж минуле (А. Адлер, Л Виготський, Я. Васильєв, С. Максименко, Ж. Нюттен, Г. Олпорт та ін.).

Однак практичний психолог $є$ i тим професіоналом, який допоможе людині усунути труднощі у стосунках 3 сучасним оточуючим середовищем і ефективно з ним взаємодіяти. Саме психолог зі своїми психологічними знаннями, практичними уміннями, компетенціями забезпечує психологічно комфортні умови, надає якісну психологічну допомогу, 
вносить позитивні зміни у процес взаємодії 3 оточуючими.

Загальновідомо, що професійна успішність майбутніх психологів буде надто скромна без активної роботи 3 людиною, яка знаходиться у складних життєвих ситуаціях.

Отже, стає очевидним, що практикуючий психолог, є однією з центральних і необхідних фігур у наданні допомоги людині, яка знаходиться у складних життєвих ситуаціях, оскільки він: допомагає осмислити складну реальність, яка іiі оточує, осягнути філософію життя, розвинути філософське мислення, закони спілкування, бажання пізнавати сутність явищ, стосунків з оточуючими; забезпечує психологічно безпечне соціальне оточення, здоровий психологічний клімат, що дозволяє кожній людині «задовольнити свої потреби в розвитку, навчанні, соціалізації» (В. Г. Панок); зміцнити та гармонізувати психічне здоров'я (I. О. Баєва); переосмислити власне життя.

Найважливішим завданням практичної психології $є$ адресна психологічна допомога різним категоріям людей. На практикуючих психологів покладена величезна відповідальність - допомогти людині активізувати власні особистісні ресурси для подолання складної життєвої ситуації, поновити почуття безпеки (психологічної), упорядкувати картину світу.

Однак студенти-психологи ще не визначають уміння розв'язувати складні життєві ситуації як провідну інтегральну професійну компетенцію психолога. Як показало недавнє дослідження, проведене на базі Миколаївського національного університету імені В. О. Сухомлинського, в уявленнях студентів про чинники успішності у професійній діяльності психолога знайшли відображення переважно окремі професійно важливі якості, а професійні компетенції, у яких відбувається взаємозв'язок окремих якостей для вирішення певних професійних завдань, не достатньо усвідомлюється. I хоча спектр професійно важливих якостей значно розширився під час навчання 3 другого по четвертий курс, тобто до моменту отримання диплому бакалавра, все ж таки професійні уміння в уявленнях про майбутню професійну діяльність не зайняли вагомого місця, а уміння розв'язувати складні життєві ситуації залишилися поза увагою студентів (Рис.1).

Як показали результати дослідження, професійні уміння ще не усвідомлюються студентами в цілісному образі професійної діяльності. Таким чином, можна зробити висновок, що майбутнім психологам під час навчання необхідно допомогти розкрити ситуаційний аспект професійної діяльності, розкрити складові професійного успіху саме в площині розв'язання складних життєвих ситуацій, сформувати психологічну готовність до їх вирішення.

У суспільстві ризику на перший план висувається готовність особистості діяти в умовах ризику, прогнозувати можливості його 


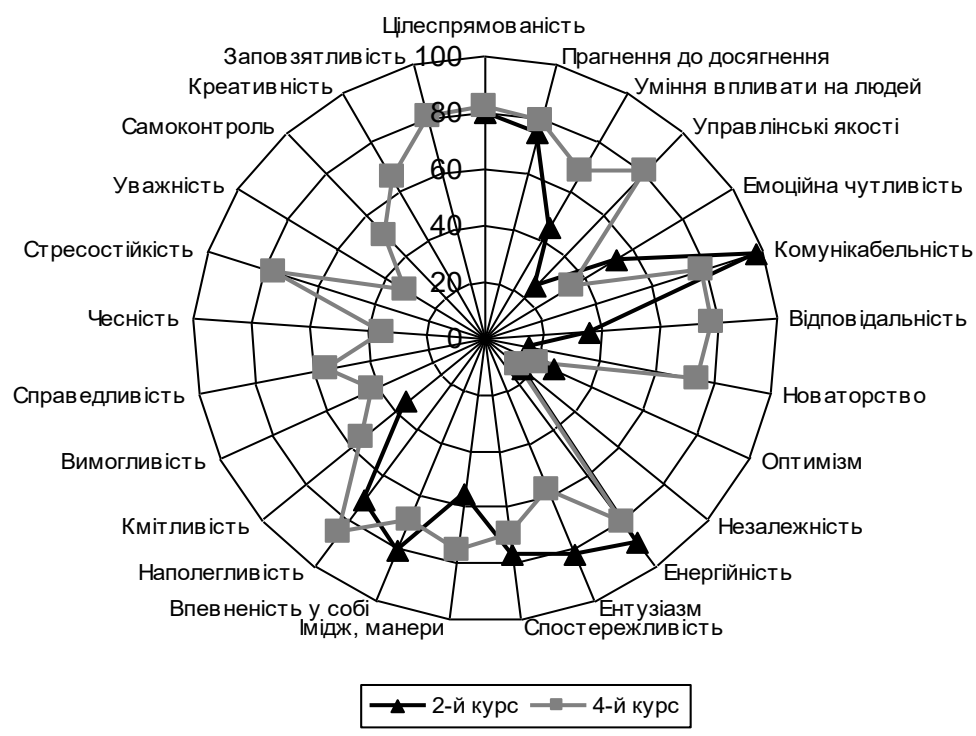

\section{Рис. 1. Зміст уявлень студентів про чинники професійної успішності психолога}

проявів, прораховувати його наслідки. Причому незалежно від того, чи виступає тут людина як самосвідомий суб’єкт життєтворчості, чи ні, вона не може уникнути ризику. За таких умов професійна успішність, має бути доповнена «культурою ризику», яка передбачає готовність особистості до постійних змін, що відбуваються як на індивідуальному, так і на професійному, суспільному рівні. Культура ризику - це, насамперед, здатність прийняття зважених і відповідальних рішень щодо свого професійного майбутнього, що передбачає адекватне розуміння, сприйняття і оцінку ризиків. Системостворювальне значення в культурі ризику має етичний компонент, оскільки прийняття відповідальних рішень має спиратися не тільки на індивідуально обрані, але й на загальновизнані параметри, визначені об' $€$ ктивною ієрархією загальнолюдських цінностей і благ та професійної етики. Дані принципи, як граничні імперативи, закладають лише граничні параметри етичного підгрунтя культури ризику, на засадах якого людина самостійно має приймати рішення про особисту відповідальність без усяких гарантій їх неминучої правильності й успішності. Таким чином, концепцією культури ризику в професійній сфері виступає здатність збирати і раціонально осмислювати інформацію для адекватного розуміння, сприйняття й оцінки ризиків та прийняття на цій основі відповідальних рішень 3 урахуванням багатомірності своєї життєвої і професійної перспективи, єдності етичного, прагматичного, комунікативного вимі- 
рів, ситуативних і глобальних вимог, а також спроможності втілювати конкретними діями ці рішення у життя, керуючись свободою вибору та професійною етикою.

Фіксація соціального контуру професійної успішності психолога в суспільстві ризику дозволяє осмислити його як відповідальне вибудовування особистості, в якому узгоджуються вимоги досягнення злагоди із самим собою та злагоди зі світом. Оскільки професіонал повинен вчитися усе життя, то головна ідея навчання умінню розв'язувати складні життєві ситуації - не встановлювати жорсткі правила і не давати готові рецепти, а формувати оптативні пропозиції, відкривати нові можливості життєвого самовибору і самоздійснення, визначати принципи особистісного розвитку, самовдосконалення. Останнє розуміється як кропітка, незупинна праця над собою, що вводить до проблемного поля професійної успішності, окрім раціональної, ще й вольову, потребово-мотиваційну і темпоральну складові [9]. У мистецтві вирішення складних життєвих ситуацій визначився специфічний інструментальний вимір, що визначається як самоздійснення. Цей вимір знайшов своє яскраве відображення у практиці психології i психотерапії. Головним тут $є$ пізнання себе, відкриття себе як об'єкта гідного уваги, що досягалося за допомогою певних практик: практики самоаналізу, метою якої є оцінка власного досвіду, практики самообмеження, як необхідної умови володіння собою, саморе- гуляції і самоконтролю, практики роботи думки над собою, спрямованої на самопроектування, моделювання і самопрограмування всієї реальності і перспективи. На інструментальному рівні професіонал не розробляє рецептів оволодіння зовнішніми атрибутами життєвого успіху, а занурює людину в етичний контекст продуктивного життя, яке має ознаки розвитку, вдосконалення, самоактуалізації особистості, конструктивних і позитивних взаємовідносин людини 3 навколишнім світом. Таким чином професійна успішність в умовах суспільства ризику, не виступаючи однозначним алгоритмом життєвого успіху, виявляється умовою успішності особистості в трансцендентному вимірі [10].

Професійна успішність в суспільстві ризику має бути доповнена культурою свободи (де складно переплітаються іiї позитивний i негативний, індивідуальний, соціальний, економічний, політичний, духовний виміри тощо) і культурою мислення з такими її компонентами, як: здатність критично мислити, креативно мислити, мислити творчо.

Висновки. Для кожної людини проблема професійної успішності як складової вирішується в координатах особистісного, індивідуального, соціального вимірів. Професійна успішність виступає чинником як індивідуального, так і суспільного розвитку. Вона репрезентує у рефлексивній формі той діапазон можливостей, які людина здатна реалізувати i реалізує в процесі власної життєдіяльності, 
відображає розуміння і дії у процесах самореалізації людини. Цей діапазон можливостей, 3 одного боку, відповідає особистим уявленням людини, а з іншого, - запитам суспільства щодо продуктивного іiі самоздійснення. Отже, проблематика професійної успішності майбутніх психологів у суспільстві ризику заслуговує особливої уваги, а переосмислення місця професійної успішності у системі життєвих цінностей і смислів виступає підгрунтям для створення основи до особистісної освітньої парадигми. Сучасна психологічна освіта має бути спрямована на формування уміння зустрічати життєві ситуації, розв'язувати їх, не порушуючи прав і свободи інших, накопичувати і аналізувати свій власний життєвий досвід, який є безцінним надбанням, користуватися ним як власним ресурсом життєвої компетентності.

\section{Список використаних джерел:}

1. Бек У. Общество риска: на пути к другому модерну / У. Бек / [пер. с нем. В. Сидельника, Н. Федоровой]. М : Прогресс-Традиция, 2000. - С. 383.

2. Глузман Н. А. Порівняльний аналіз підходів до розуміння компетентності та компетенції в професійній освіти / Н.А. Глузман // Науковий вісник Миколаївського державного університету : [зб. наук. праць. / за заг. ред. В.Д. Будака, О.М. Пєхоти]. - Миколаїв: МДУ, 2008. - Вип. 23, Т. 2. - С. $67-79$.

3. Ершова Н. Г. Психолого-педагогическое сопровождение формирования конкурентоспособности специалистов / Н.Г. Ершова. - Волгоград : ВЛГИФК, 2000. С. $27-29$.

4. Зимняя И. А. Ключевые компетенции - новая паради- гма результата образования / И.А. Зимняя // Высшее образование сегодня. - 2005. - № 11. - С. 14 - 20.

5. Компетентісний підхід у сучасній освіті: світовий досвід та українські перспективи: [за заг. ред. О.В. Овчарук]. - К. : К.І.С., 2004. - 112 c.

6. Маслоу А. Мотивация и личность / А. Маслоу [пер. с англ. А.М. Татлыбаевой]. - СПб. : Евразия, 2001. - 478 c.

7. Панок В. Г. Практична психологія. Теоретикометодологічні засади розвитку: Монографія / Панок В.Г. - Чернівці: Технодрук, 2010. - 486 с.

8. Сохань Л. В. Життєтворчість як мистецтво жити / Сохань Л.В. // Психологія і педагогіка життєтворчості: навч.-метод. посібник- К., 1996. - С. 156 - 167.

9. Степаненко Н. Б. Концептуальні контури філософії мистецтва жити: витоки i перспективи / Н. Б. Степаненко // Мультиверсум. Філософський альманах: Зб. наук. праць / Гол. Ред. В. В. Лях. - Вип. 88. К., 2009. -C. $63-74$.

\section{References (Transliteration):}

1. Bek U. Obschestvo riska: na puti $\mathrm{k}$ drugomu modernu / U. Bek / [per. s nem. V. Sidelnika, N. Fedorovoy]. - M : Progress-Traditsiya, 2000. - S. 383.

2. Gluzman N. A. PorIvnyalniy analIz pIdhodIv do rozumInnya kompetentnostI ta kompetentsIYi $\mathrm{v}$ profesIynIy osvIti / N.A. Gluzman // Naukoviy vIsnik MikolaYivskogo derzhavnogo unIversitetu : [zb. nauk. prats. / za zag. red. V.D. Budaka, O.M. PEhoti]. - MikolaYiv: MDU, 2008. Vip. 23, T. 2. - S. $67-79$.

3. Ershova N. G. Psihologo-pedagogicheskoe soprovozhdenie formirovaniya konkurentosposobnosti spetsialistov / N.G. Ershova. - Volgograd : VLGIFK, 2000. - S.27 - 29.

4. Zimnyaya I. A. Klyuchevyie kompetentsii - novaya paradigma rezultata obrazovaniya / I.A. Zimnyaya // Vyisshee obrazovanie segodnya. - 2005. - \# 11. - S. $14-20$.

5. Kompetenisniy pidhid u suchasnly osviti: svitoviy dosvid ta ukrayinski perspektivi: [za zag. red. O.V. Ovcharuk]. K. : K.I.S., 2004. $-112 \mathrm{~s}$. 
6. Maslou A. Motivatsiya i lichnost / A. Maslou [per. s angl. A.M. Tatlyibaevoy]. - SPb. : Evraziya, 2001. - 478 s.

7. Panok V. G. Praktichna psihologIya. TeoretikometodologIchnI zasadi rozvitku: Monograftya / Panok V.G. - ChernIvtsI: Tehnodruk, 2010. - 486 s.

8. Sohan L. V. ZhittetvorchIst yak mistetstvo zhiti / Sohan L.V. // PsihologIya i pedagogIka zhittetvorchosti: navch.metod. posIbnik- K., 1996. - S. $156-167$.

9. Stepanenko N. B. Kontseptualni konturi filosofiyi mistetstva zhiti: vitoki I perspektivi / N. B. Stepanenko // Multiversum. filosofskiy almanah: Zb. nauk. prats / Gol. Red. V. V. Lyah. - Vip. 88. - K., 2009. -S. $63-74$.

\section{Chugueva Inna}

PhD (Psychology), associate professor of the Department of Psychology in Sukhomlynskyi Mykolaiv National University, Mykolaiv (Ukraine)

\section{Kuznetsova Svitlana}

Lecturer of the Department of Psychology in Sukhomlynskyi Mykolaiv National University, Mykolaiv (Ukraine)

\section{PROFESSIONAL SUCCESS OF FUTURE PSYCHOLOGISTS IN THE RISK SOCIETY}

\section{ABSTRACT}

There is considered the problem of professional success of future psychologists in the society of risk. The main psychological components of professional success are described. There is considered the connection of professional success in the risk society with the ability to solve difficult life situations. The expediency of attracting of future psychologists in solving difficult life situations as a value-semantic basis of the personal educational paradigm is substantiated.

It has been determined that professional success as a concept has many components of its content, it includes individual, social, economic, functional and activity components, which reveal the meaning of this concept both in general and in every concrete example. Professional success is a certain result, which is created in the process of assimilation, mastering and realization of a person in his or her professional activity.

Considering the problem of professional success of future psychologists, it is noted that the professional and personal aspects which are interrelated and mutually related, constitute the essence of the problems of professional development of the individual.

The conception of new goals and means, ideological orientation sand forms of organization of educational activity is offered to be taken in to account of requirements of formation and development of the ability to handle both problem situations in general and with situations of risk in particular.

It is emphasized that in the society of risk the professional task of a practicing psychologist acquires a new meaning - the formation of a special culture of social and individual life with the observance of there quirements of anthropological, social, psychological safety.

It is shown that the profession of psychologist is becoming more practical_orientated, and psychologists are necessary specialists who are called to help the society and every citizen to find answer stourgent issues of the present, to provide psychological support to those who find 
themselves in difficult life situations.

According to the results of the research, it has been shown that professional skills are not yet understood by students in a holistic way of professional activity. Thus, we can conclude that we should help the future psychologists to reveal the situational aspect of professional activity, to reveal the components of professional success precisely in the area of solving difficult life situations, to form psychological readiness for their solution during their professional training.

Keywords: professional achievement, risk society, difficult life situation, personal educational paradigm, individual livelihoods.

\section{Чугуева Инна Евгеньевна}

Кандидат психологических наук, доцент кафедры психологии, Николаевский национальный университет имени В. А. Сухомлинского, г. Николаев (Украина)

\section{Кузнецова Светлана Валериевна}

Преподаватель кафедры психологии, Николаевский национальный университет имени В. А. Сухомлинского, г. Николаев (Украина)

\section{ПРОФЕССИОНАЛЬНАЯ УСПЕШНОСТЬ БУДУЩИХ ПСИХОЛОГОВ В ОБЩЕСТВЕ РИСКА}

Аннотация. В исследовании рассмотрена проблема профессиональной успешности будущих психологов в обществе риска. Охарактеризованы основные психологические компоненты профессиональной успешности.

Исследована связь профессиональной успешности в обществе риска с умением решать сложные жизненные ситуации. Обоснована целесообразность привлечения будущих психологов в решение сложных жизненных ситуаций, как ценностно-смысловой основы личностной образовательной парадигмы.

Определено, что профессиональная успешность, как понятие, имеет множество смысловых составляющих, в частности, она содержит в себе индивидуальный, социальный, экономический, функциональный компоненты, которые раскрывают смысл этого понятия и в общем, и в каждом конкретном примере.

Профессиональная успешность - это определенный результат, который создается в процессе усвоения, овладения и осуществления человеком своей профессиональной деятельности.

Рассматривая проблему профессиональной успешности будущих психологов, подчеркнуто, что профессиональный и личностный аспекты, которые являются взаимообусловленными, составляют суть проблематики профессионального становления личности.

Предложено осмысление новых целей и способов, мировоззренческих ориентиров и форм организации образовательной деятельности с учетом требований формирования и развития, что позволит справляться как с проблемными ситуациями в целом, так и с ситуациями риска в частности.

Делается ударение на то, что в условиях общества риска профессиональная задача практикующего психолога приобретает новое 
значение - формирование у человека особенной культуры социальной и индивидуальной жизнедеятельности с учетом требований антропологической, социальной, психологической безопасности.

Показано, что профессия психолога становится более практически ориентированной, а психолог-профессионалом, который призван помочь найти выход из сложной жизненной ситуации как конкретной личности, так и обществу в целом путем предоставления психологической помощи.

Кроме указанного, по результатам исследования показано, что профессиональные умения еще не осознаются студентами в целостном образе профессиональной деятельности.

Таким образом, можно сделать вывод, что будущим психологам во время обучения необходимо помочь раскрыть ситуационный аспект профессиональной деятельности, раскрыть составляющие профессионального успеха именно в плоскости разрешения сложных жизненных ситуаций, сформировать психологическую готовность к их решению.

Ключевые слова: профессиональная успешность, общество риска, сложная жизненная ситуация, личностная образовательная парадигма, индивидуальная жизнедеятельность. 